\title{
Performance of white oat cultivars in response to nitrogen fertilization and trinexapac-ethyl
}

\section{Desempenho produtivo de cultivares de aveia branca em resposta à adubação nitrogenada e ao trinexapac-ethyl}

\author{
José Henrique Bizzarri Bazzo ${ }^{1 *}$; Carlos Roberto Riede ${ }^{2}$; Klever Márcio Antunes \\ Arruda $^{2}$; Carolina Pereira Cardoso ${ }^{3}$; Isabela Franzoni ${ }^{4}$; Inês Cristina de Batista \\ Fonseca $^{5}$; Claudemir Zucareli ${ }^{5}$
}

\begin{abstract}
The application of $\mathrm{N}$ at the appropriate time and dose can increase oat crop efficiency by increasing grain yield through changes in production components. High doses of $\mathrm{N}$, depending on the genotype and the environment, can result in plant lodging, which can be addressed with the use of growth retardants. The aim of this study was to evaluate the yield components, lodging, and productivity of white oat cultivars cultivated at two growing locations under different $\mathrm{N}$ levels with trinexapac-ethyl growth retardant. Two assays (with and without the application of the growth retardant agent) were used in the experiments, which were set up in the region of Londrina and Mauá da Serra, Parana State, Brazil, in a randomized block design with split plots and four replications. The plots consisted of four white oat cultivars (IPR Afrodite, IPR Artemis, URS Corona, and URS Guria) and the subplots of four doses of $\mathrm{N}\left(0,30,60\right.$, and $\left.90 \mathrm{~kg} \mathrm{ha}^{-1}\right)$. Plant height, number of panicles per unit area, number of grains per panicle, thousand grain weight, lodging of plants, and grain yield were evaluated. The growth retardant decreased plant height and lodging at the both growing locations. Furthermore, the growth retardant in combination with $\mathrm{N}$ topdressing increased the number of panicles per unit area. Thus, the increase in grain yield with the application of a growth retardant was dependent on the characteristics of the plant growth environment. The response of genotypes to $\mathrm{N}$ fertilization was also dependent on the soil and climatic characteristics of the environment.
\end{abstract}

Key words: Avena sativa L. Growth regulator. Lodging. Nitrogen. Productivity.

\section{Resumo}

A aplicação de nitrogênio $(\mathrm{N})$ no momento e dose adequados pode aumentar sua eficiência na cultura da aveia, incrementando o rendimento de grãos por meio de alterações nos componentes de produção. No entanto, altas doses deste nutriente podem resultar no acamamento das plantas, o que pode ser contornado com uso de redutores de crescimento. As respostas dos cereais as doses de $\mathrm{N}$ e ao redutor são variáveis de acordo com o genótipo e o ambiente de cultivo. Neste sentido, objetivou-se avaliar os componentes de rendimento, o acamamento e a produtividade de grãos de cultivares de aveia branca

1 Prof., Departamento de Agronomia, Centro Universitário Filadélfia, UNIFIL, Londrina, PR, Brasil. E-mail: agro.bazzo@gmail.com

2 Drs., Pesquisadores, Instituto Agronômico do Paraná, IAPAR, Londrina, PR, Brasil. E-mail: crriede@iapar.br; klever@iapar.br

3 Discente, Curso de Mestrado, Programa de Pós-Graduação em Agronomia, Universidade Estadual Paulista "Júlio de Mesquita Filho", UNESP, Botucatu, SP, Brasil. E-mail: carolina.cardosopc@gmail.com

4 Enga Agr ${ }^{\mathrm{a}}$, Londrina, PR, Brasil. E-mail: isabela_franzoni@hotmail.com

5 Profs. Drs., Departamento de Agronomia, Universidade Estadual de Londrina, UEL, Londrina, PR, Brasil. E-mail: inescbf@uel. br; claudemircca@uel.br

* Author for correspondence 
granífera cultivadas em dois ambientes, sob diferentes doses de nitrogênio, associadas ao redutor de crescimento trinexapac-ethyl. Os experimentos foram conduzidos nos municípios de Londrina e Mauá da Serra, Paraná, sob o delineamento experimental de blocos casualizados com parcelas subdivididas, com quatro repetições. As parcelas constaram de quatro cultivares de aveia branca (IPR Afrodite, IPR Artemis, URS Corona e URS Guria) e as subparcelas de quatro doses de nitrogênio (N) em cobertura $\left(0,30,60\right.$ e $\left.90 \mathrm{~kg} \mathrm{ha}^{-1}\right)$. Em cada local foram conduzidos dois experimentos, com e sem aplicação do redutor de crescimento. Foram avaliados: altura de plantas, número de panículas $\mathrm{m}^{-2}$, número de grãos por panícula, massa de mil grãos, acamamento de plantas e produtividade de grãos. Nas condições em que os experimentos foram conduzidos, a aplicação do redutor de crescimento diminui a altura e o acamamento de plantas e, quando associado à adubação nitrogenada, eleva o número de panículas $\mathrm{m}^{-2}$. O aumento da produtividade de grãos, com a utilização de redutor de crescimento, depende das características do ambiente de cultivo, sendo observado somente em Mauá da Serra. A resposta das cultivares à fertilização nitrogenada de cobertura também depende das características edafoclimáticas dos locais de cultivo.

Palavras-chave: Acamamento. Avena sativa L. Nitrogênio. Produtividade. Redutor de crescimento.

\section{Introduction}

The productive potential of white oat, besides being related to the climatic conditions of the environment, is associated with the intrinsic characteristics of the genotypes and their interaction with the management techniques (SILVA et al., 2012). The genetic improvement programs of oats in Southern Brazil have developed cultivars that are more productive and better adapted to different environmental conditions. These characteristics have made the genotypes also more responsive to $\mathrm{N}$ application (KOLCHINSKI; SCHUCH, 2002). Thus, a high productive performance can be achieved by $\mathrm{N}$ fertilization (CECCON et al., 2004), as $\mathrm{N}$ is quantitatively one of the most important elements favoring the growth and development of the plant, yield components, and grain quality (KOLCHINSKI; SCHUCH, 2004).

Peruzzo (2000) reported that the supply of $\mathrm{N}$ at the tillering stage of wheat increases the efficiency in the use of the nutrient with an increase in grain yield, which, according to Bredemeier and Mundstock (2001), occurs through stimulation of production components.

According to Sangoi et al. (2007), the efficiency of $\mathrm{N}$ use by the plant is influenced by plant genotype, which can differ in the number of tillers, maturity period, and grain yield potential. The authors also reported that these differences may cause different responses at the time of application and the level of N used. Hence, Teixeira Filho et al. (2007), using different genotypes of wheat, verified that $\mathrm{N}$ fertilization increased the number of ears per area, productivity, and weight of one thousand grains of all cultivars.

The productivity of white oat grains is positively influenced by the use of high levels of N (CECCON et al., 2004). However, this practice can lead to a higher vegetative development and result in increased plant height, with consequent lodging of plants, negatively affecting the production and quality of grain (ZAGONEL; FERNANDES, 2007).

One of the strategies used in combination with high levels of $\mathrm{N}$ fertilization in order to achieve high agronomic yields, without the occurrence of plant lodging, is the adoption of cultivars of smaller stature or the management of plant size with the application of plant growth retardants (PGR) (PENCKOWSKI et al., 2010). Trinexapac-ethyl, which acts on the plants to reduce the elongation of internodes during the vegetative stage by acting at the end of the metabolic pathway of the biosynthesis of gibberellic acid, is one of the most important PGRs (RAJALA; PELTONEN-SAINIO, 2001). The drastic fall in the level of gibberellic acid, which affects the elongation of internodes, causes the inhibition of plant growth (RADEMACHER, 2000). 
Studies in wheat (ESPINDULA et al., 2010), white oat (KASPARY et al., 2015), and rice (ALVAREZ et al., 2007) have shown the viability of the use of growth retardants in the reduction of plant height and the consequent lodging of plants.

This study aimed to evaluate the yield components, plant lodging, and grain yield of cultivars of white oats grown in two environments, under different levels of $\mathrm{N}$ and the growth retardant trinexapac-ethyl.

\section{Materials and Methods}

The experiments were conducted in two growing environments in Londrina and Mauá da Serra, state of Paraná, which are contrasting in soil type and climatic characteristics. In the city of Londrina-PR, the experiment was carried out at the Experimental Farm of the Agronomic Institute of Paraná (IAPAR), on a eutrophic Red Latosol located at $23^{\circ} 23^{\prime} \mathrm{S}$ and $51^{\circ} 11^{\prime} \mathrm{W}$, at an elevation of height of $610 \mathrm{~m}$. The climate of the region is $\mathrm{Cfa}$, described as humid subtropical with hot summers, according to the Köppen classification. In the municipality of Mauá, Serra-PR, the experiment was conducted at Farm Estância $3 \mathrm{M}$, on a dystrophic Red Latosol, located at $23^{\circ} 58^{\prime} \mathrm{S}$ and $51^{\circ} 19^{\prime} \mathrm{W}$, at an elevation of 847 $\mathrm{m}$. The climate of the region is type $\mathrm{Cfb}$, described as temperate mesothermic with fresh summers, according to the Köppen classification. Rainfall and temperature data were obtained through IAPAR meteorological station records (Figure 1).

Figure 1. Rainfall (total accumulated during the ten-day period) and average temperature in the experimental period in Londrina-PR (A) and Mauá da Serra-PR (B), 2014.

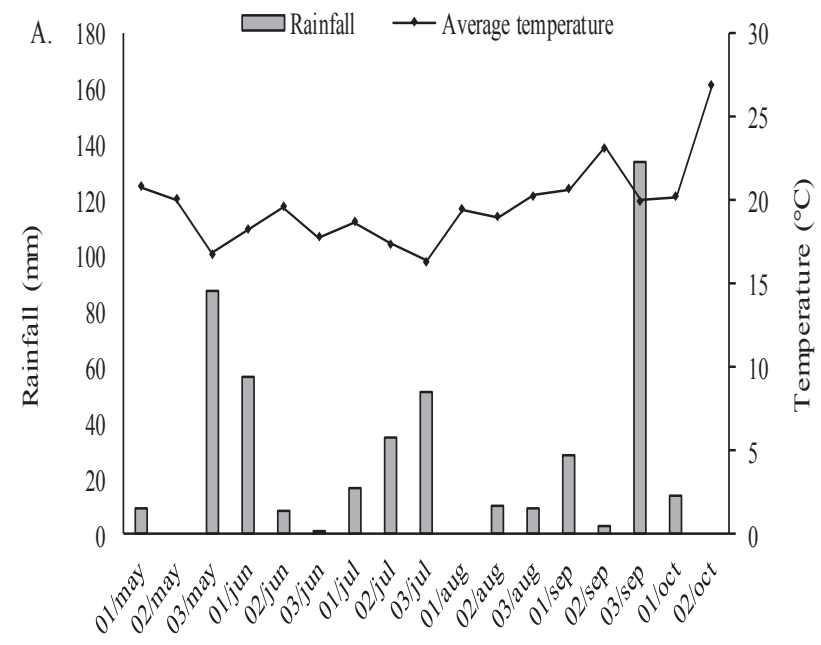

ten-day period - months

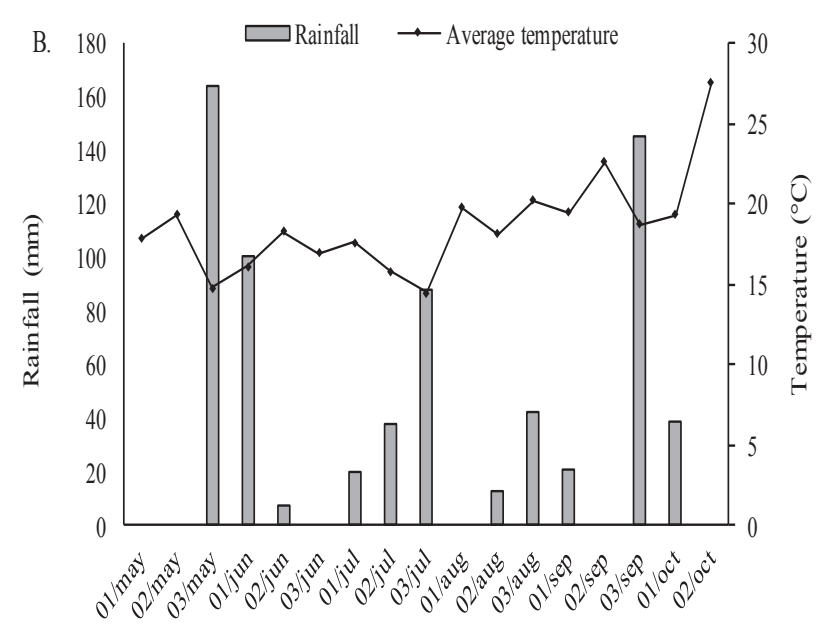

ten-day period - months
The chemical characteristics of the soil at depths of $0-10 \mathrm{~cm}$ and $10-20 \mathrm{~cm}$, determined before the experiments, in Londrina-PR were as follows: 0 to $10 \mathrm{~cm}-\mathrm{pH}\left(\mathrm{CaCl}_{2}\right) 5.40,5.34 \mathrm{cmol}_{\mathrm{c}} \mathrm{dm}^{-3} \mathrm{H}+\mathrm{Al}^{3+}$, $5.22 \mathrm{cmol}_{\mathrm{c}} \mathrm{dm}^{-3} \mathrm{Ca}^{2+}, 3.08 \mathrm{cmol}_{\mathrm{c}} \mathrm{dm}^{-3} \mathrm{Mg}^{2+}, 0.95$ $\mathrm{cmol}_{\mathrm{c}} \mathrm{dm}^{-3} \mathrm{~K}^{+}, 32.0 \mathrm{mg} \mathrm{dm}^{-3} \mathrm{P}$, and $16.98 \mathrm{~g} \mathrm{dm}^{-3}$ organic matter; and 10 to $20 \mathrm{~cm}-\mathrm{pH}\left(\mathrm{CaCl}_{2}\right) 5.00$, $5.76 \mathrm{cmol}_{\mathrm{c}} \mathrm{dm}^{-3} \mathrm{H}+\mathrm{Al}^{3+}, 4.57 \mathrm{cmol}_{\mathrm{c}} \mathrm{dm}^{-3} \mathrm{Ca}^{2+}$, $2.38 \mathrm{cmol}_{\mathrm{c}} \mathrm{dm}^{-3} \mathrm{Mg}^{2+}, 0.65 \mathrm{cmol}_{\mathrm{c}} \mathrm{dm}^{-3} \mathrm{~K}^{+}, 17.6 \mathrm{mg}$ $\mathrm{dm}^{-3} \mathrm{P}$, and $16.12 \mathrm{~g} \mathrm{dm}^{-3}$ organic matter. In Mauá da Serra-PR, the soil characteristics were: 0 to 10 $\mathrm{cm}-\mathrm{pH}\left(\mathrm{CaCl}_{2}\right) 4.90,7.20 \mathrm{cmol}_{\mathrm{c}} \mathrm{dm}^{-3} \mathrm{H}+\mathrm{Al}^{3+}$, $6.80 \mathrm{cmol}_{\mathrm{c}} \mathrm{dm}^{-3} \mathrm{Ca}^{2+}, 1.64 \mathrm{cmol}_{\mathrm{c}} \mathrm{dm}^{-3} \mathrm{Mg}^{2+}, 0.50$ $\mathrm{cmol}_{\mathrm{c}} \mathrm{dm}^{-3} \mathrm{~K}^{+}, 23.5 \mathrm{mg} \mathrm{dm}^{-3} \mathrm{P}$, and $29.92 \mathrm{~g} \mathrm{dm}^{-3}$ organic matter; and 10 to $20 \mathrm{~cm}-\mathrm{pH}\left(\mathrm{CaCl}_{2}\right) 4.80$, $7.75 \mathrm{cmol} \mathrm{dm}^{-3} \mathrm{H}+\mathrm{Al}^{3+}, 5.97 \mathrm{cmol}_{\mathrm{c}} \mathrm{dm}^{-3} \mathrm{Ca}^{2+}, 1.43$ $\mathrm{cmol}_{\mathrm{c}} \mathrm{dm}^{-3} \mathrm{Mg}^{2+}, 0.20 \mathrm{cmol}_{\mathrm{c}} \mathrm{dm}^{-3} \mathrm{~K}^{+}, 11.5 \mathrm{mg} \mathrm{dm}^{-3}$ $\mathrm{P}$, and $27.73 \mathrm{~g} \mathrm{dm}^{-3}$ organic matter. 
The experimental design for each environment was randomized blocks with subdivided plots, with four replications. The plots consisted of four cultivars of white oat (IPR Afrodite, IPR Artemis, URS Corona, and URS Guria), while the subplots consisted of four levels of $\mathrm{N}(0,30,60$, and $90 \mathrm{~kg}$ $\left.\mathrm{ha}^{-1}\right)$. Two experiments were conducted at each site, with and without application of growth retardant.

The main agronomic characteristics of the cultivars are: IPR Afrodite (medium maturity; moderate resistance to lodging; average plant height; and released in 2012 by IAPAR); IPR Artemis (medium maturity; moderate susceptibility to lodging; average plant height; and released in 2016 by IAPAR); URS Corona (medium maturity; moderate susceptibility to lodging; above average plant height; and released in 2010 by the UFRGS); and URS Guria (early maturity; susceptible to lodging; above average plant height; and released in 2010 by the UFRGS) (CBPA, 2014).

The cultivars were sown mechanically, under no-tillage system and in an area previously growed with soybean crop in the cities of Londrina and Mauá da Serra, on May 8, 2014 and May 12, 2014 respectively, at a density of 300 viable seeds per unit area $\left(\mathrm{m}^{-2}\right)$. The subplots comprised of six lines of five meters in length and spacing between rows of $0.17 \mathrm{~m}$, with floor area of $5.1 \mathrm{~m}^{2}$.

Based on the chemical characteristics of the soil of the experimental areas, the basic mineral fertilization in the sowing furrow, constant for all treatments, was calculated as $30 \mathrm{~kg} \mathrm{ha}^{-1}$ of $\mathrm{N}, 90 \mathrm{~kg}$ ha $^{-1}$ of $\mathrm{P}_{2} \mathrm{O}_{5}$, and $30 \mathrm{~kg} \mathrm{ha}^{-1}$ of $\mathrm{K}_{2} \mathrm{O}$ in the municipality of Londrina-PR and $20 \mathrm{~kg} \mathrm{ha}^{-1}$ of N, $60 \mathrm{~kg} \mathrm{ha}^{-1}$ of $\mathrm{P}_{2} \mathrm{O}_{5}$, and $20 \mathrm{~kg} \mathrm{ha}^{-1}$ of $\mathrm{K}_{2} \mathrm{O}$ in the municipality of Mauá da Serra-PR, using the formula 10-30-10 for both growing environments. Nitrogen topdressing was carried out at the tillering phase, in the form of urea $(45 \% \mathrm{~N})$.

In experiments using the growth retardant, trinexapac-ethyl was applied during the stem elongation phase, between the $1^{\text {st }}$ and $2^{\text {nd }}$ perceptible nodes. The level of trinexapac-ethyl used was 125 g a.i. ha ${ }^{-1}$, corresponding to $400 \mathrm{~mL} \mathrm{ha}^{-1}$ of the commercial product Moddus ${ }^{\circledR}$, applied by a constant pressure backpack spray of $30 \mathrm{lb} \mathrm{pol}^{-2}$, pressurized by compressed $\mathrm{CO}_{2}$ equipped with two tips with XR 110-020 flat fan jet nozzles. The volume of the syrup was proportional to $200 \mathrm{~L} \mathrm{ha}^{-1}$.

The phytosanitary treatments for the control of diseases and other crop treatments were performed according to the need and the recommendations for the crop (CBPA, 2014). The harvest was performed after the grain reached the harvest stage characterized by hardening of the caryopsis, plants with dry aspect, and grain with moisture content below $20 \%$. The following evaluations were performed:

Plant height: the length of five plants selected at random from each experimental plot during the grain filling period, from soil level to the end of the panicle with mean results expressed in $\mathrm{cm}$.

Number of panicles per unit area $\left(\mathrm{m}^{-2}\right)$ : determined at the time of harvest by counting the number of panicles from $1.0 \mathrm{~m}$ of row of plants in in a plot, then the number of panicles per unit area $\left(\mathrm{m}^{2}\right)$ was calculated by multiplying the number of panicles per meter by the spacing between the rows of plants $(0.17 \mathrm{~m})$.

The number of grains per panicle: initially the grains of ten panicles were randomly harvested in each plot and, after their complete separation, were counted manually.

Weight of thousand grains: obtained by counting and weighing eight replicates of 100 grains per plot. The average value was multiplied by 10 to obtain the value of one thousand grain weight.

Lodging: obtained through visual observations, at maturity stage of the plants, using a scale of 0 to 10 , with 10 representing $100 \%$ of the plants and 0 referring to no lodged plants in a plot.

Grain yield: determined by the grain harvested from the plot area. After mechanical threshing, the grain was weighed and the was data transformed to $\mathrm{kg} \mathrm{ha}^{-1}$ at $13 \%$ moisture level. 
The data were submitted to analysis of normality and homogeneity and, later, to analysis of joint variance for the experiments with and without application of the growth retardant. This was performed separately for each experimental site. The means of the cultivars were compared by using the Tukey test, while the effect of the growth retardant was determined by using the $\mathrm{F}$ test. The effect of $\mathrm{N}$ levels was assessed by using regression analysis, up to the $2^{\text {nd }}$ degree, at $5 \%$ level of significance.

\section{Results and Discussion}

\section{Londrina}

Isolated effect of growth retardant was verified for plant height and of cultivar for number of grains per panicle and lodging. There was no interaction effect of growth retardant and level of $\mathrm{N}$ fertilization on the number of panicles per unit area and plant lodging. No significant effect of the growth retardant, cultivar, level of $\mathrm{N}$ fertilization, and their interaction on weight of thousand grains and grain yield.

Plant height was influenced significantly by the application of the growth retardant, with a mean reduction in plant height of $14.6 \%(15.24 \mathrm{~cm})$ compared to treatments without the growth retardant (Table 1). When absorbed by the plant, trinexapacethyl acts selectively to reduce the level of active gibberellic acid, which promotes cell elongation, and induces a temporary inhibition or reduction of the rate of growth of the plant (SILVA et al., 2012). Thus, the reduction in the number and length of plant cells affects the elongation of internodes during the vegetative period. This reduces plant height without causing morphological deformation on the stem (TAIZ; ZEIGER, 2004).

Table 1. Mean plant height of four cultivars of white oat with application of growth retardant trinexapac-ethyl, as observed in Londrina-PR, 2014.

\begin{tabular}{cc}
\hline Growth retardant & Plant height $(\mathrm{cm})$ \\
\hline With & $89.45 \mathrm{~B}$ \\
Without & $104.69 \mathrm{~A}$ \\
\hline CV1 (\%) & 14.43 \\
CV2 (\%) & 5.49 \\
\hline
\end{tabular}

Means followed by the same letter in a column did not significantly differ, according to the $\mathrm{F}$ test $(p<0.05)$.

The number of panicles per unit area was adjusted to quadratic functions in response to $\mathrm{N}$ topdressing (Figure 2). With the application of the growth retardant, the maximum rate of $\mathrm{N}$ fertilization was $35.96 \mathrm{~kg} \mathrm{~N}^{-1}$ and, while in the absence of the growth retardant, the minimum $\mathrm{N}$ application rate was $44.86 \mathrm{~kg} \mathrm{~N} \mathrm{ha}^{-1}$. At levels of 30 and 60 $\mathrm{kg} \mathrm{N} \mathrm{ha}^{-1}$, the treatments without trinexapac-ethyl displayed a lower number of panicles per unit area, while at the other $\mathrm{N}$ application levels no significant difference in the number of panicles was observed between treatments with and without application of the growth retardant.
The differentiated behavior between the treatments with and without application of the growth retardant can be explained by the fact that its application results in reduced plant height (Table 1). This likely resulted in favorable conditions for the development of fertile tillers due to a higher capacity for absorption of solar radiation and, consequently, production of a greater number of panicles per unit area. Castro and Kluge (1999) reported that tillering in annual grasses is promoted by high light intensity, which explains the results observed in this study for the treatments with the growth retardant. 
The lower values of number of panicles observed per unit area in the treatments without the growth retardant can be explained by the greater development of leaf area due to the increase of $\mathrm{N}$, causing shading of the lower leaves. This, according to Fornasieri Filho and Fornasieri (2006), increases apical dominance, reducing the development of the lateral or tiller buds and decreasing the number of panicles per unit area.

Figure 2. Number of panicles $\mathrm{m}^{-2}$ of four white oat cultivars in response to topdressing nitrogen levels and growth retardant trinexapac-ethyl, as observed in Londrina-PR, 2014.

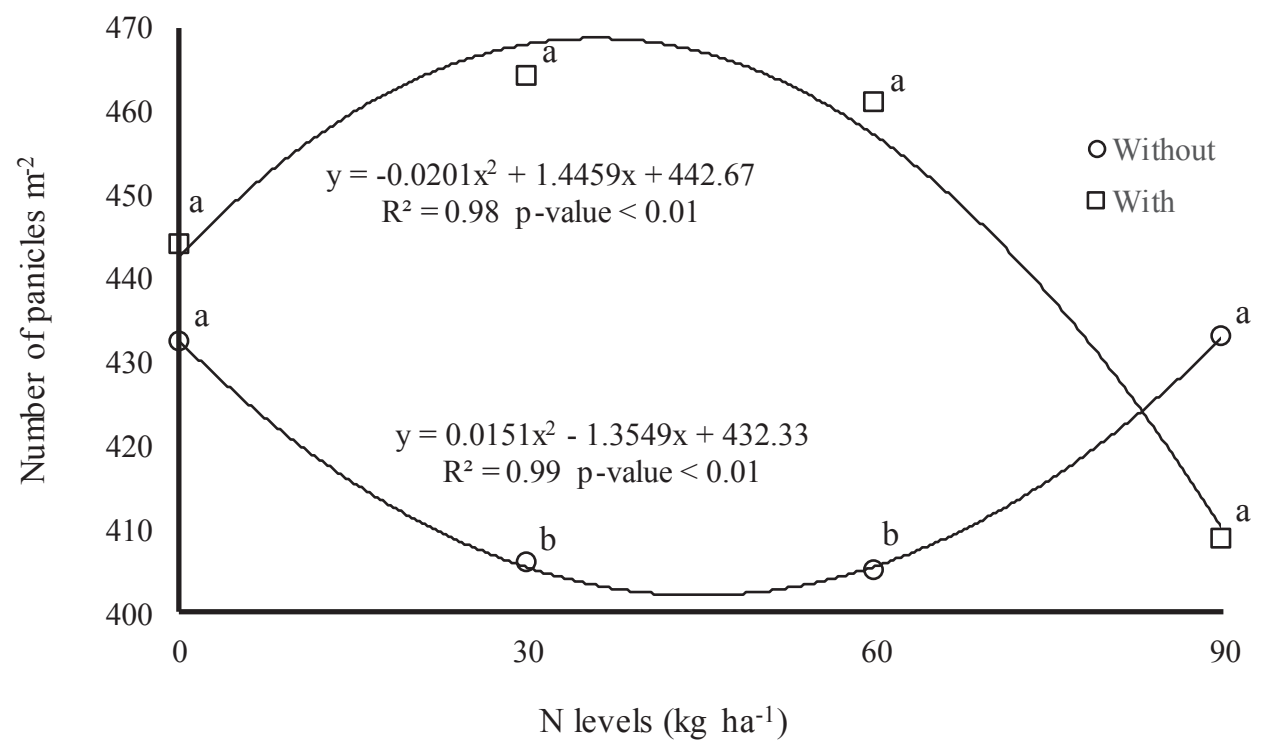

Thus, the result that the change in the density of panicles per area with application of the growth retardant was due to more compact plants, caused by the reduction in plant height causing photoassimilates that would be destined to the elongation of the plant, in the absence of growth retardant, to be redirected to the production of fertile tillers and, as a result, the generation of a greater number of panicles per unit area.

For the number of grains per panicle, the cultivar IPR Artemis presented higher values than the cultivar URS Corona (Table 2). Arf et al. (2012) evaluated the use of different trinexapacethyl levels $\left(0,50,100,150\right.$, and $200 \mathrm{~g}$ a.i. ha $\left.{ }^{-1}\right)$ in four upland rice cultivars (Caiapó, BRS Primavera,
BRS Soberana, and IAC 202), and also observed significant differences between cultivars.

Regarding plant lodging, the cultivar IPR Afrodite presented the lowest value (5.78\%). The cultivars IPR Artemis, URS Corona, and URS Guria did not differ among themselves, presenting $26.56 \%, 33.28 \%$, and $35.15 \%$ of lodged plants, respectively (Table 2). The cultivar IPR Afrodite displayed the lowest value of lodged plants $(5.78 \%)$. This result corroborates with results of several authors whom observed a variation in the lodging of plants between different genotypes in experiments investigating levels (ESPINDULA et al., 2010) and forms of split $\mathrm{N}$ topdressing (COSTA et al., 2013). 
Table 2. Mean values for the number of grains per panicle and lodging of plants of four cultivars of white oat, as observed in Londrina-PR, 2014.

\begin{tabular}{ccc}
\hline Cultivars & Number of grains per panicle & Lodging (\%) \\
\hline IPR Afrodite & $750.22 \mathrm{AB}$ & $5.78 \mathrm{~B}$ \\
IPR Artemis & $822.00 \mathrm{~A}$ & $26.56 \mathrm{~A}$ \\
URS Corona & $686.68 \mathrm{~B}$ & $33.28 \mathrm{~A}$ \\
URS Guria & $716.28 \mathrm{AB}$ & $35.15 \mathrm{~A}$ \\
\hline CV1 $(\%)$ & 25.60 & 88.68 \\
CV2 (\%) & 13.81 & 68.30 \\
\hline
\end{tabular}

Means followed by the same letter in a column did not significantly differ according to the Tukey's test $(p<0.05)$.

For all the cultivars, the increase of $\mathrm{N}$ application rate linearly increased the percentage of lodged plants, with a higher rate of increase for the treatments without the plant growth retardant (Figure 3). At the levels of 60 and $90 \mathrm{~kg} \mathrm{~N} \mathrm{ha}^{-1}$, the application of the growth retardant resulted in reduced lodging of plants compared to treatments without application of the growth retardant. This result shows that the use of the growth retardant efficiently reduced plant lodging at higher levels of N. In other studies in rice (ARF et al., 2012), white grain oat (HAWERROTH et al., 2015), and wheat (PENCKOWSKI et al., 2010), reductions in plant lodging induced by trinexapac-ethyl were also observed.

Figure 3. Lodging of plants in four white oat cultivars in response to topdressing nitrogen levels and growth retardant trinexapac-ethyl, as observed in Londrina-PR, 2014.

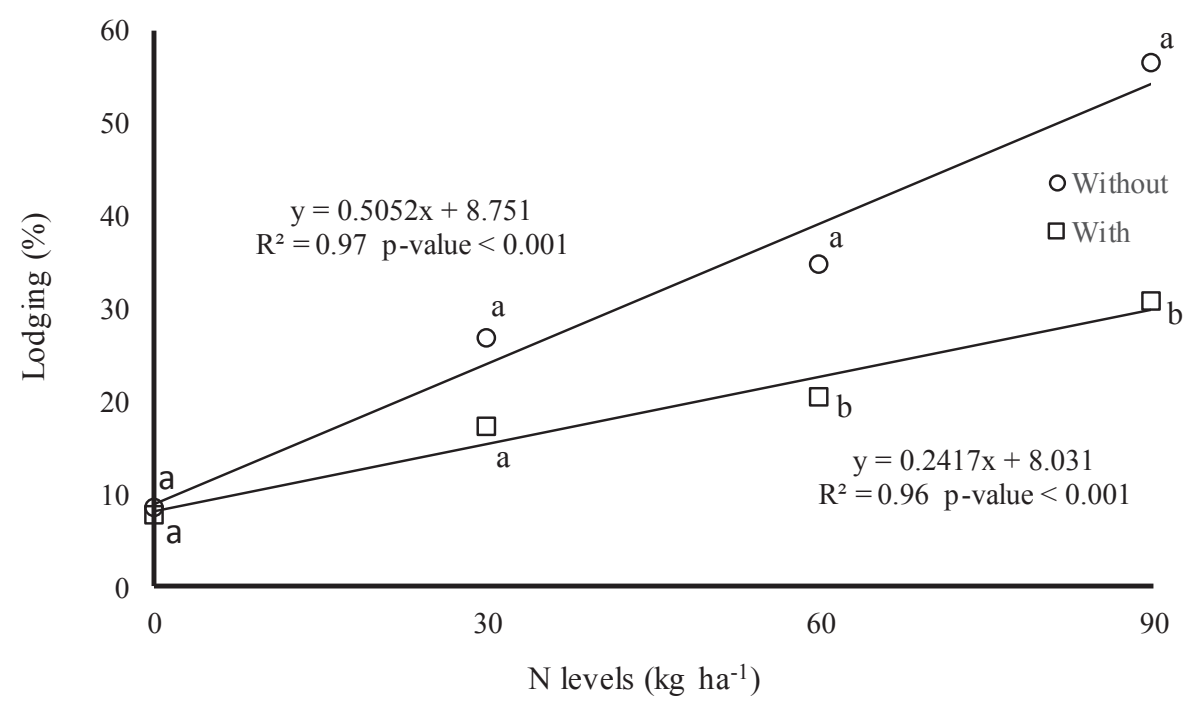

The reduction in plant height, due to the application of the growth retardant (Table 1), decreased the rate of plant lodging, especially at higher levels of $\mathrm{N}$ applied as topdressing fertilizer (Figure 3), with a reduction in plant lodging of $1 \%$; $9.4 \% ; 17.5 \%$, and $25.6 \%$ at levels of $0,30,60$, and $90 \mathrm{~kg} \mathrm{~N} \mathrm{ha}{ }^{-1}$, respectively.

\section{Mauá da Serra}

There was an interaction effect between the growth retardant and cultivar on plant height, weight of a thousand grains, and grain yield. There was an isolated effect of the growth retardant on the number of panicles per unit area and number of 
grains per panicle. The cultivar type also affected the number of panicles per unit area and number of grains per panicle, while the $\mathrm{N}$ topdressing affected plant height and the number of panicles per unit area. For weight of one thousand grains, there was an interaction effect between genotype and level of topdressing N. However, for plant lodging, a significant effect of the triple interaction among the factors plant growth regulator, cultivar, and level of $\mathrm{N}$ during topdressing was observed.

The application of the growth retardant reduced plant height in all cultivars (Table 3), demonstrating the efficiency of the product in reducing stem elongation, regardless of the size of the cultivar. For the average height of all cultivars, it was observed that the use of the plant growth regulator decrease plant height by $26.68 \%$ compared to the treatments without the growth retardant. In the absence of the growth retardant, no significant difference in plant height was observed between the cultivars. With the application of trinexapac-ethyl, the cultivar URS Guria presented greater height $(101.54 \mathrm{~cm})$. Schwerz et al. (2015) also observed a significant difference in plant height between cultivars as a function of the application of a growth retardant on three wheat cultivars (TBIO Mestre, TBIO Iguaçú, and TBIO Itaipú) and five levels of $\mathrm{N}(0,40,80$, 120 , and $160 \mathrm{~kg} \mathrm{ha}^{-1}$ ).

Table 3. Mean values of plant height, weight of one thousand grains, and grain yield of four cultivars of white oat with and without application of the growth retardant trinexapac-ethyl, as observed in Mauá da Serra-PR, 2014.

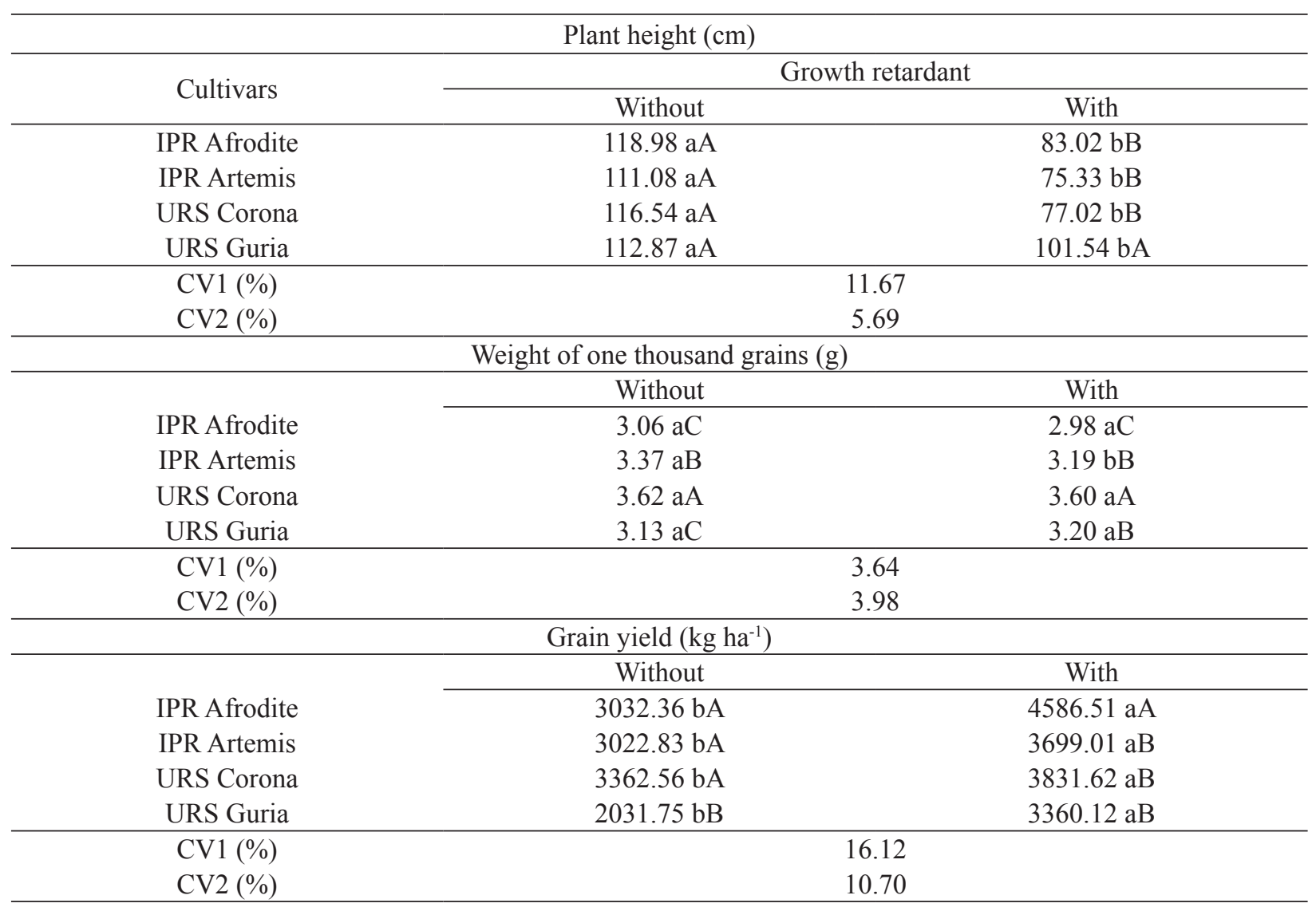

Means followed by the same lowercase letter in the row and uppercase letter in the column did not significantly according to the $\mathrm{F}$ test and Tukey's test $(p<0.05)$, respectively. 
The different responses of cultivars in plant height, depending on the application of the growth retardant, are related to the recommended level of trinexapac-ethyl (100 to 125 g i.a. ha ${ }^{-1}$ ), regardless of the cultivars, which can respond differently to the application level of the product (RODRIGUES et al., 2003).

Plant height was adjusted to an increasing linear equation with the increase of the $\mathrm{N}$ topdressing level, regardless of the cultivar (Figure 4). This result corroborates with other studies in wheat, in which the increase in $\mathrm{N}$ fertilizer also resulted in the increase in plant height (ESPINDULA et al., 2010; ZAGONEL; FERNANDES, 2007; ZAGONEL et al., 2002). Theago et al. (2014) obtained a quadratic response of the $\mathrm{N}$ level on plant height, with a maximum point at $148 \mathrm{~kg} \mathrm{~N}^{-1}$. In contrast, Prando et al. (2013) and Teixeira Filho et al. (2012) showed that $\mathrm{N}$ topdressing did not influence plant height.

Figure 4. Plant height of white oat cultivars in response to different levels of nitrogen, as observed in Mauá da SerraPR, 2014.

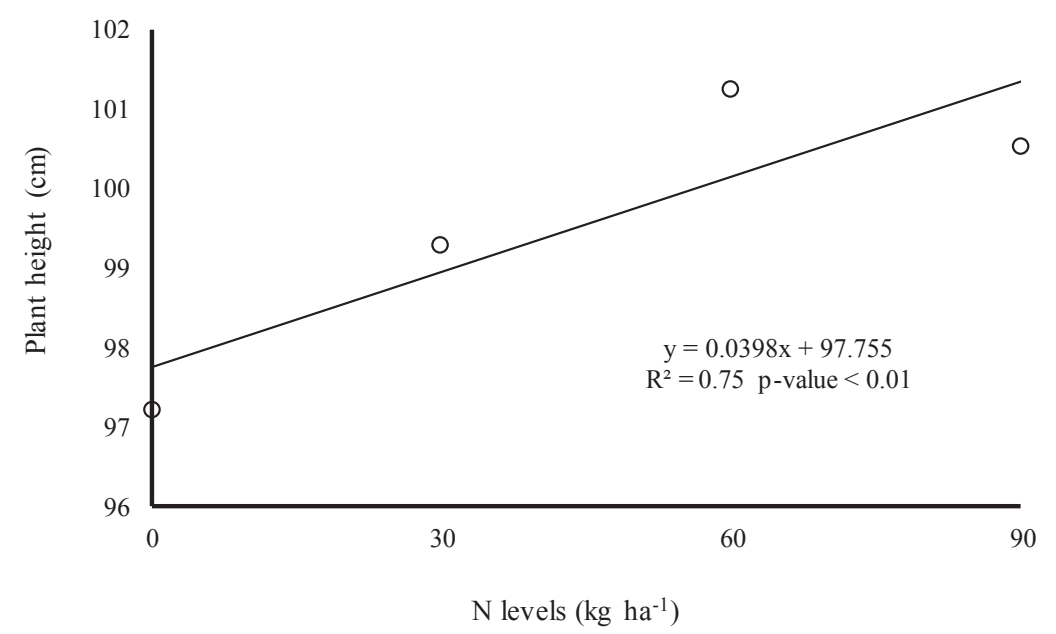

According to Marschner (1995), the application of high levels of $\mathrm{N}$ in cereals increases the production of phytohormones, plant growth, and development promoters responsible for the processes of cell division and expansion, increasing stem elongation and, consequently, plant height. This is in line with the results obtained in the present study.

The number of panicles per unit area was positively influenced by the application of the growth retardant, with the number of panicles presenting $10 \%$ higher values compared to treatment without application of the growth retardant (Table 4). Zagonel and Fernandes (2007) did not observe an effect of trinexapac-ethyl on the number of ears per unit area in three wheat cultivars. However, Zagonel et al. (2002) observed that the application of trinexapac-ethyl increased the number of productive structures per unit area. This variability in yield components with application of trinexapacethyl is likely due to the climatic variation of each location and the interaction with the cultivar used (PENCKOWSKI et al., 2009).

Among the cultivars used in this study, URS Corona presented the lowest number of panicles per unit area (Table 4). Kolchinski and Schuch (2002) evaluated the yield components, including grain yield, of four cultivars of white oat (CTC 5, UFRGS 15, UFRGS 19, and UPF 18) and also showed differences between the genotypes, which probably occurs due to differences in the tillering potential of the genotypes and the interaction with the crop environment. 
The number of panicles per unit area was adjusted to a linear equation increasing in response to the increase in $\mathrm{N}$ application level (Figure 5). According to Kolchinski and Schuch (2002), the number of reproductive units in oats is defined at the beginning of the vegetative period. Thus, the increased level of $\mathrm{N}$ in the plant during tillering contributed to the increase in the number of tillers and, consequently, to the number of panicles per unit area. This is justified by the activity of $\mathrm{N}$ on the development of tillers, the growth of tissues, and the differentiation of vegetative and reproductive buds (MALAVOLTA et al., 1997).

Table 4. Mean values of the number of panicles $\mathrm{m}^{-2}$ (PAN) and number of grains per panicle (GP) with application of the growth retardant trinexapac-ethyl in white oats cultivars, as observed in Mauá da Serra-PR, 2014.

\begin{tabular}{ccc}
\hline Growth retardant & \multicolumn{2}{c}{ Characteristics } \\
\cline { 2 - 3 } With & PAN & $60.01 \mathrm{~B}$ \\
Without & $397.91 \mathrm{~A}$ & $67.45 \mathrm{~A}$ \\
\hline CV1 (\%) & $358.50 \mathrm{~B}$ & 19.26 \\
CV2 (\%) & 21.22 & 13.35 \\
\hline Cultivars & 15.37 & GP \\
\hline IPR Afrodite & PAN & $66.47 \mathrm{~A}$ \\
IPR Artemis & $387.16 \mathrm{AB}$ & $55.44 \mathrm{~B}$ \\
URS Corona & $405.72 \mathrm{~A}$ & $70.78 \mathrm{~A}$ \\
URS Guria & $343.80 \mathrm{~B}$ & $62.22 \mathrm{AB}$ \\
\hline CV1 (\%) & $376.14 \mathrm{AB}$ & 19.26 \\
CV2 (\%) & 21.22 & 13.35 \\
\hline
\end{tabular}

Means followed by the same letter in a column did not significantly differ according to the F test and Tukey's test $(p<0.05)$, respectively.

Figure 5. Number of panicles $\mathrm{m}^{-2}$ of white oat cultivars in response to different levels of nitrogen, as observed in Mauá da Serra-PR, 2014.

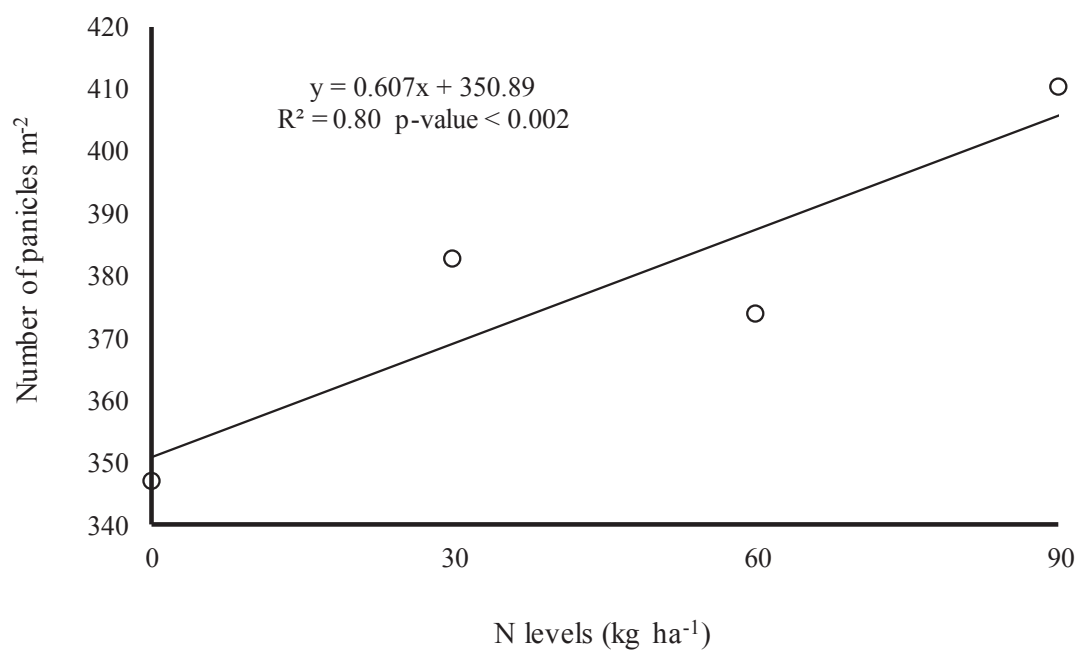


Regarding the number of grains per panicle, plants treated with trinexapac-ethyl displayed a reduction of 7.44 grains per panicle compared to untreated plants (Table 4). Alvarez et al. (2007) reported that this can be related to the time of application of trinexapac-ethyl to the plant, which occurs during the differentiation of the primordium of the panicle, interfering with its initial formation that involves constant cell division, such as formation of the panicle ramifications, number of ears per branching, and floral organs, reducing the number of ears and grains per panicle.

Table 4 shows that the lowest number of grains per panicle was obtained with the cultivar IPR Artemis. Several studies have been carried out in different cultivars of wheat and rice crops by evaluating the use of growth retardant and $\mathrm{N}$ application level and also showed a significant effect of plant genotype on the number of grains per panicle (ARF et al., 2012; SCHWERZ et al., 2015; TEIXEIRA FILHO et al., 2012, 2007).
It is worth mentioning that there was an increase in the number of panicles per unit area with the application of the growth retardant, which may have contributed to the reduction in the number of grains per panicle, due to competition among fertile tillers for photoassimilates.

One thousand-grain weight was affected by the interactions between the growth retardant and cultivar (Table 3) and between the level of $\mathrm{N}$ and cultivar (Figure 6). For interaction between the growth retardant and cultivar, most of the cultivars were not influenced by application of the growth retardant, except IPR Artemis, which had a lower thousand-grain weight with the application of trinexapac-ethyl $(5.34 \%$ reduction). The cultivar URS Corona presented the highest one thousandgrain weight both with and without application of the growth retardant (Table 3).

Figure 6. Weight of one thousand grains of four white oat cultivars in response to different levels of nitrogen, as observed in Mauá da Serra-PR, 2014.

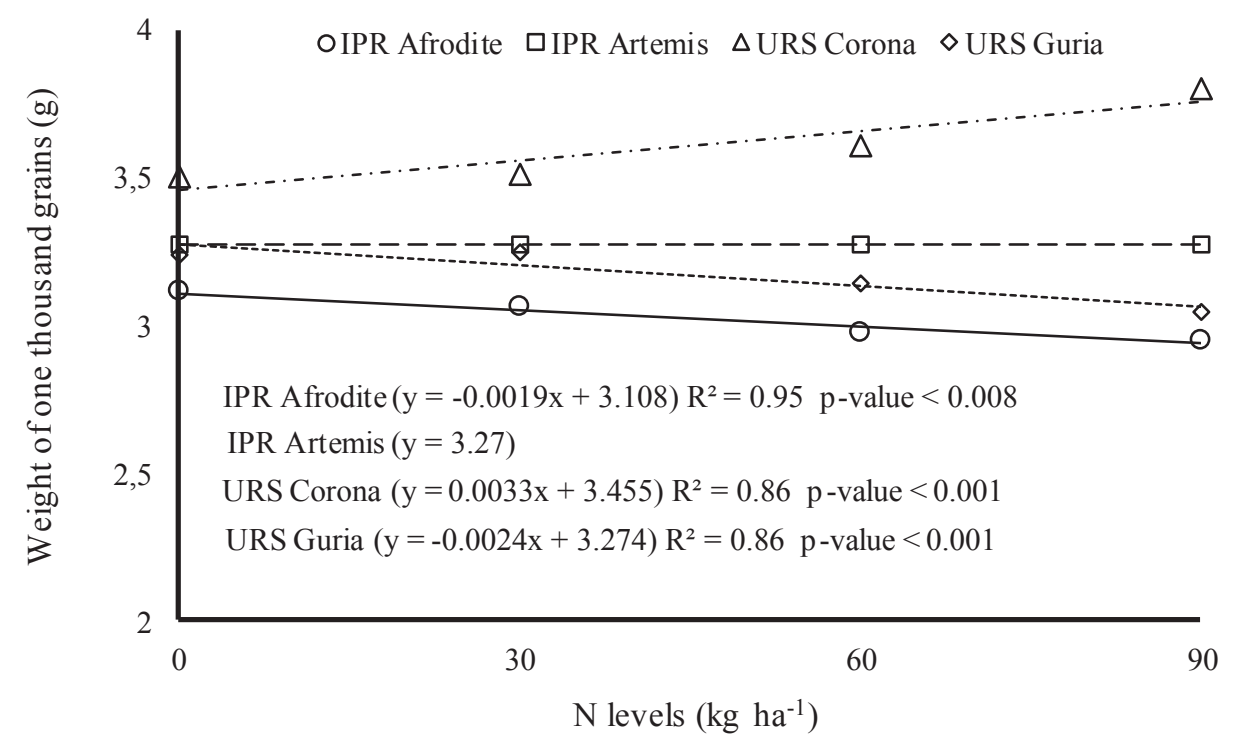

For the interaction of $\mathrm{N}$ and cultivar, the cultivars IPR Afrodite and URS Guria presented a linear reduction in the weight of one thousand grains with

increasing $\mathrm{N}$ application rate (Figure 6). However, there was no response to $\mathrm{N}$ fertilization for the cultivar IPR Artemis. The cultivar URS Corona 
showed increasing linear adjustment of the $\mathrm{N}$ level for weight of one thousand grains. Table 5 shows that for all $\mathrm{N}$ levels $\left(0,30,60\right.$, and $\left.90 \mathrm{~kg} \mathrm{~N} \mathrm{ha}^{-1}\right)$, the highest and lowest values of one thousand-grain weight were observed for the cultivars URS Corona and IPR Afrodite, respectively.

For all the cultivars and $\mathrm{N}$ levels studied, there was a reduction of plant lodging with the application of the growth retardant, in exception of the cultivar URS Guria, which showed no significant difference with and without application of the growth retardant at the level of $90 \mathrm{~kg} \mathrm{~N} \mathrm{ha}^{-1}$ (Table 6).

In treatments without application of the growth retardant, the percentage of lodging in the cultivar IPR Afrodite was adjusted to a quadratic equation with a maximum point at $79.77 \mathrm{~kg} \mathrm{~N} \mathrm{ha-1}$. For other cultivars, there was no response to different levels of N (Figure 7A). Cultivars IPR Artemis,
URS Corona, and URS Guria showed, on average, $85.62 \%, 91.25 \%$, and $93.9 \%$ of plant lodging, respectively. For the treatments with application of the growth retardant, there was a linear increase in lodging of plants with increasing rate of $\mathrm{N}$ fertilizer for the cultivars IPR Artemis and URS Guria, with a higher rate of increase for the cultivar URS Guria. As for the cultivars IPR Afrodite and URS Corona, no significant effect of $\mathrm{N}$ level on plant lodging was observed, with no lodging of plants observed in these cultivars (Figure 7B). Similar studies investigating the influence of trinexapacethyl and $\mathrm{N}$ fertilization in different genotypes on the lodging of plants also reported increase in the plant lodging with increasing $\mathrm{N}$ application level (PENCKOWSKI et al., 2009, 2010). Pagliosa et al. (2013) did not observe any effect of the growth retardant and $\mathrm{N}$ fertilization on the lodging of wheat plants.

Table 5. Mean values of weight of thousand grains of four white oat cultivars at different levels of nitrogen, as observed in Mauá da Serra-PR, 2014.

\begin{tabular}{ccccc}
\hline \multirow{2}{*}{ Cultivars } & \multicolumn{4}{c}{ Levels of $\mathrm{N}\left(\mathrm{kg} \mathrm{ha}^{-1}\right)$} \\
\cline { 2 - 5 } & 0 & 30 & 60 & 90 \\
\hline IPR Afrodite & $3.12 \mathrm{C}$ & $3.06 \mathrm{C}$ & $2.97 \mathrm{C}$ & $2.96 \mathrm{C}$ \\
IPR Artemis & $3.34 \mathrm{AB}$ & $3.21 \mathrm{BC}$ & $3.30 \mathrm{~B}$ & $3.26 \mathrm{~B}$ \\
URS Corona & $3.51 \mathrm{~A}$ & $3.52 \mathrm{~A}$ & $3.61 \mathrm{~A}$ & $3.79 \mathrm{~A}$ \\
URS Guria & $3.24 \mathrm{BC}$ & $3.25 \mathrm{~B}$ & $3.15 \mathrm{~B}$ & $3.04 \mathrm{C}$ \\
\hline CV1 (\%) & \multicolumn{5}{c}{3.64} \\
CV2 (\%) & \multicolumn{5}{c}{3.98} \\
\hline
\end{tabular}

Means followed by the same letter in a column did not significantly differ according to the Tukey's test $(p<0.05)$.

Table 6. Mean values of plant lodging in four white oat cultivars with and without growth retardant regulator trinexapac-ethyl and different levels of nitrogen, as observed in Mauá da Serra-PR, 2014.

\begin{tabular}{ccccccccc}
\hline & \multicolumn{7}{c}{ Levels of N $\left(\mathrm{kg} \mathrm{ha}^{-1}\right)$} \\
\cline { 2 - 9 } Cultivars & \multicolumn{9}{c}{0} & \multicolumn{9}{c}{60} & \multicolumn{2}{c}{90} \\
\cline { 2 - 9 } & Without & With & Without & With & Without & With & Without & With \\
\hline IPR Afrodite & $36.25 \mathrm{aC}$ & $0.00 \mathrm{bB}$ & $66.25 \mathrm{aB}$ & $0.00 \mathrm{bC}$ & $81.25 \mathrm{aAB}$ & $0.00 \mathrm{bB}$ & $83.75 \mathrm{aA}$ & $1.25 \mathrm{bC}$ \\
IPR Artemis & $72.50 \mathrm{aB}$ & $0.00 \mathrm{bB}$ & $92.50 \mathrm{aA}$ & $22.50 \mathrm{bB}$ & $68.75 \mathrm{aB}$ & $17.50 \mathrm{bB}$ & $90.00 \mathrm{aA}$ & $51.25 \mathrm{bB}$ \\
URS Corona & $86.25 \mathrm{aAB}$ & $0.00 \mathrm{bB}$ & $95.00 \mathrm{aA}$ & $0.00 \mathrm{bC}$ & $95.00 \mathrm{aA}$ & $1.25 \mathrm{bB}$ & $88.75 \mathrm{aA}$ & $0.00 \mathrm{bC}$ \\
URS Guria & $96.25 \mathrm{aA}$ & $68.75 \mathrm{bA}$ & $95.00 \mathrm{aA}$ & $77.50 \mathrm{bA}$ & $95.00 \mathrm{aA}$ & $80.00 \mathrm{bA}$ & $94.50 \mathrm{aA}$ & $82.50 \mathrm{aA}$ \\
\hline CV1 (\%) & \multicolumn{7}{c}{36.75} \\
CV2 (\%) & \multicolumn{7}{c}{17.99} \\
\hline
\end{tabular}

Means followed by the same lowercase letter in a row and uppercase letter in a column do not significantly differ according to the Tukey's test $(p<0.05)$. 
The increase in $\mathrm{N}$ fertilization increased plant height (Figure 4) and this phenomenon led to high percentages of lodged plants (Figures 7A and 7B). As shown in Table 3, the application of the growth retardant reduced plant height, decreasing plant lodging, even at higher levels of N (Figure 7B). With the use of the growth retardant, lodging was not observed at all $\mathrm{N}$ levels tested for the cultivars IPR Afrodite and URS Corona, while the cultivars IPR Artemis and URS Guria showed that plant lodging reduced from $85.62 \%$ and $93.9 \%$ to $22.81 \%$ and $77.18 \%$, at the mean levels of $\mathrm{N}$ application, respectively.

Another factor that may have contributed to high levels of lodging of plants in this study is the occurrence of a high number of panicles per unit area in response to $\mathrm{N}$ fertilization, which probably occurred due to the stimulation of the production, development, and survival of tillers, which increased with the weight of the plant, reducing the resistance of the stem and leading to the lodging of plants.

Figure 7. Lodging of plants of four white oat cultivars in response to different levels of nitrogen, without (A) and with (B) application of the growth retardant trinexapac-ethyl, as observed in Mauá da Serra-PR, 2014.

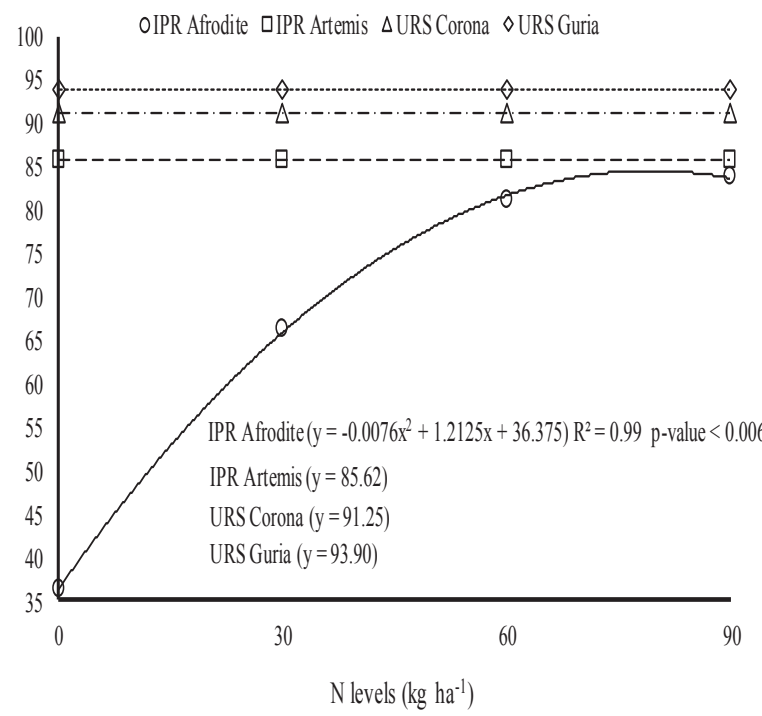

Table 3 details the breakdown of the interaction between the cultivar and the plant growth factors for grain yield, showing that the oat cultivars did not respond in the same way to the application of the growth retardant. Trinexapac-ethyl increased the yield of grains in all cultivars, with the cultivar IPR Afrodite presenting the highest yield. In this case, the highest number of grains per panicle of the cultivar IPR Afrodite was probably the character that most influenced productivity differences among the cultivars. Sangoi et al. (2007) reported that the number of grains per spike of wheat is one of the yield components that is more closely related to the production of grains.

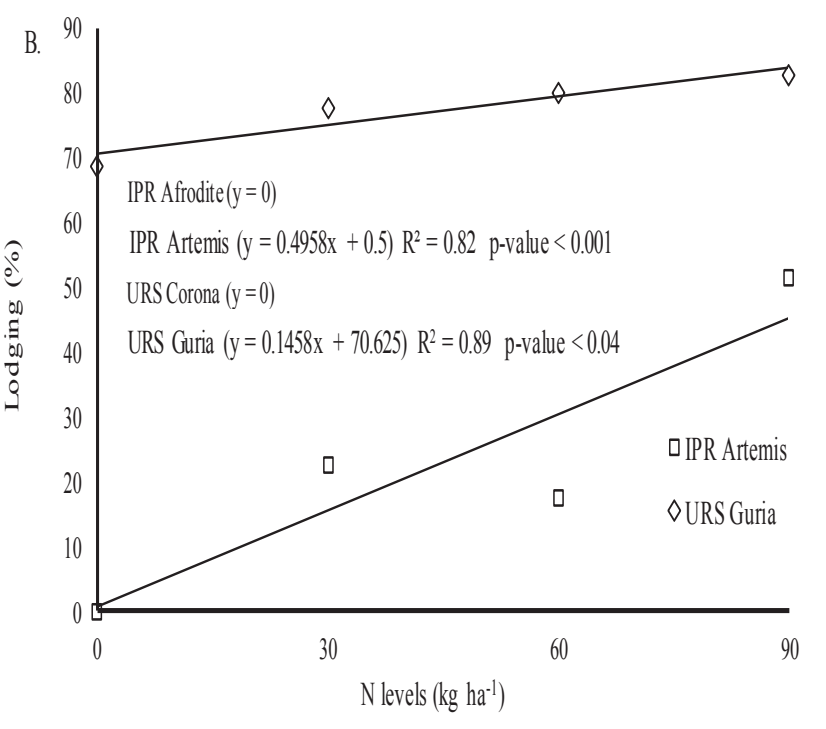

In the absence of trinexapac-ethyl, the best performance for grain yield was observed in the cultivars IPR Afrodite, IPR Artemis, and URS Corona, with no significant difference between them, while the cultivar URS Guria presented the lowest grain yield. Zagonel et al. (2002) and Penckowski et al. (2009) also observed increased grain yield in wheat with the application of the growth retardant trinexapac-ethyl.

The positive effect of trinexapac-ethyl on grain yield may be the consequence of the reduction in plant size on lodging of plants, resulting in alterations in the architecture, and the increase in 
the number of panicles per unit area. In this study, the cultivars that showed the highest percentage of lodged plants, both with and without application of the growth retardant (Table 6), were those that presented low grain yields (Table 3 ).

Topdressing fertilization did not increase grain yield of white oat cultivars, revealing that the lowest level used $\left(30 \mathrm{~kg} \mathrm{~N} \mathrm{ha}^{-1}\right.$ basal dressing and $0 \mathrm{~kg} \mathrm{~N}$ $\mathrm{ha}^{-1}$ topdressing) was enough for the expression of the productive potential of the cultivars. This result is associated with the organic matter content of the soil, which was $29.92 \mathrm{~g} \mathrm{dm}^{-3}$ and $27.73 \mathrm{~g} \mathrm{dm}^{-3}$ at $0-10 \mathrm{~cm}$ and $10-20 \mathrm{~cm}$ depths, respectively. Thus, the organic matter present in the soil and the mineralized $\mathrm{N}$ from the straw of the previous crop (soybean) provided the necessary amount of $\mathrm{N}$ for the crop to reach the maximum yield.

\section{Conclusions}

Under the conditions used in this study, the application of the growth retardant reduced the height and lodging of plants and, when combined with topdressing $\mathrm{N}$ fertilization, increased the number of panicles per unit area. The increase in grain yield with the use of the growth retardant depends on the characteristics of the cultivation environment, as observed only in Mauá da Serra. The response of the cultivars to topdressing $\mathrm{N}$ fertilization also depends on the climatic characteristics of the cultivation locations.

\section{References}

ALVAREZ, R. C. F.; CRUSCIOL, C. A. C.; RODRIGUES, J. D.; ALVAREZ, A. C. C. Aplicação de reguladores vegetais na cultura de arroz de terras altas. Acta Scientiarum Agronomy, Maringá, v. 29, n. 1, p. 241249, 2007. DOI: 10.4025 /actasciagron.v29i2.258

ARF, O.; NASCIMENTO, V.; RODRIGUES, R. A. F.; ALVAREZ, R. C. F.; GITTI, D. C.; SÁ, M. E. Uso de etiltrinexapac em cultivares de arroz de terras altas. Pesquisa Agropecuária Tropical, Goiânia, v. 42, n. 2, p. 150-158, 2012. DOI: $10.1590 / \mathrm{S} 1983-40632012000200008$
BREDEMEIER, C.; MUNDSTOCK, C. M. Disponibilidade de nitrogênio e sua relação com o afilhamento e o rendimento de grãos de aveia. Ciência Rural, Santa Maria, v. 31, n. 2, p. 205-211, 2001. DOI: 10.1590/S0103-84782001000200003

CASTRO, P. R. C.; KLUGE, R. A. Ecofisiologia de cultivos anuais: trigo, milho, soja, arroz e mandioca. São Paulo: Nobel, 1999. 126 p.

CECCON, G.; GRASSI FILHO, H.; BICUDO, S. J. Rendimento de grãos de aveia branca (Avena sativa L.) em densidades de plantas e doses de nitrogênio. Ciência Rural, Santa Maria, v. 34, n. 6, p. 1723-1729, 2004. DOI: 10.1590/S0103-84782004000600009

COMISSÃO BRASILEIRA DE PESQUISA DE AVEIA - CBPA. Indicações técnicas para cultura da aveia. Castro: Fundação ABC, 2014. 136 p.

COSTA, L.; ZUCARELI, C.; RIEDE, C. R. Parcelamento da adubação nitrogenada no desempenho produtivo de genótipos de trigo. Revista Ciência Agronômica, Fortaleza, v. 44, n. 2, p. 215-224, 2013. DOI: Disponível em: http://ccarevista.ufc.br/seer/index.php/ccarevista/ article/view/1845/793. Acesso em: 26 jun. 2019.

ESPINDULA, M. C.; ROCHA, V. S.; SOUZA, M. A.; GROSSI, J. A. S.; SOUZA, L. T. Efeitos de reguladores de crescimento na elongação do colmo de trigo. Acta Scientiarum Agronomy, Maringá, v. 32, n. 1, p. 109-116, 2010. DOI: 10.4025/actasciagron.v32i1.94310.4025/ actasciagron.v32i1.943

FORNASIERI FILHO, D.; FORNASIERI, J. L. Manual da cultura do arroz. Jaboticabal: Funep, 2006. 589 p.

HAWERROTH, M. C.; SILVA, J. A. G.; SOUZA, C. A.; OLIVEIRA, A. C.; LUCHE, H. S.; ZIMMER, C. M.; HAWERROTH, F. J.; SCHIAVO, J.; SPONCHIADO, J. C. Redução do acamamento em aveia-branca com uso do regulador de crescimento etil-trinexapac. Pesquisa Agropecuária Brasileira, Brasília, v. 50, n. 2, p. 115-125, 2015. DOI: $10.1590 / \mathrm{S} 0100-204 X 2015000200003$

KASPARY, T. E.; LAMEGO, F. P.; BELLÉ, C.; KULCZYNSKI, S. M.; PITTOL, D. Regulador de crescimento na produtividade e qualidade de sementes de aveia branca. Planta Daninha, Viçosa, MG, v. 33, n. 4, p. 739-750, 2015. DOI:.1590/S0100-83582015000400012

KOLCHINSKI, E. M.; SCHUCH, L. O. B. Produtividade e utilização de nitrogênio em aveia em função de épocas de aplicação do nitrogênio. Revista Brasileira de Agrociência, Pelotas, v. 8, n. 2, p. 117-121, 2002. Disponível em: https://periodicos.ufpel.edu.br/ojs2/ index.php/CAST/article/view/440. Acesso em: 26 jun. 2019. 
KOLCHINSKI, E. M.; SCHUCH, L. O. B. Relações entre a adubação nitrogenada e a qualidade de grãos e de sementes em aveia branca. Ciência Rural, Santa Maria, v. 34 , n. 2 , p. $379-383$, 2004. DOI: $10.1590 / \mathrm{S} 0103-$ 84782004000200007

MALAVOLTA, E.; VITTI, G. C.; OLIVEIRA, S. A. Avaliação do estado nutricional da planta - princípios e aplicações. 2. ed. Piracicaba: Associação Brasileira para o Estudo da Potassa e do Fosfato, 1997. 319 p.

MARSCHNER, H. Mineral nutrition of higher plants. $2^{\text {th }}$ ed. San Diego: Academic Press, 1995. 889 p.

PAGLIOSA, E. E.; BENIN, G.; BIEZUS, E.; BECHE, E.; SILVA, C. L.; MARCHESE, J. A.; MARTIN, T. N. Trinexapac-ethyl e adubação nitrogenada na cultura do trigo. Planta Daninha, Viçosa, MG, v. 31, n. 3, p. 623630, 2013. DOI: $10.1590 / \mathrm{S} 0100-83582013000300014$

PENCKOWSKI, L. H.; ZAGONEL, J.; FERNANDES, E. C. Nitrogênio e redutor de crescimento em trigo de alta produtividade. Acta Scientiarum Agronomy, Maringá, v. 31, n. 3, p. 473-479, 2009. DOI: 10.4025/actasciagron. v31i3.1048

PENCKOWSKI, L. H.; ZAGONEL, J.; FERNANDES, E. C. Qualidade industrial do trigo em função do trinexapacethyl e doses de nitrogênio. Ciência e Agrotecnologia, Lavras, v. 34, n. 6, p. 1492-1499, 2010. DOI: 10.1590/ S1413-70542010000600020

PERUZZO, G. Nitrogênio no seu trigo. Revista Cultivar Grandes Culturas, Pelotas, v. 2, n. 16, p. 20-22, 2000. DOI: https://www.grupocultivar.com.br/revistas/338

PRANDO, A. M.; ZUCARELI, C.; FRONZA, V.; OLIVEIRA, F. A.; OLIVEIRA JÚNIOR, A. O. Características produtivas do trigo em função de fontes e doses de nitrogênio. Pesquisa Agropecuária Tropical, Goiânia, v. 43, n. 1, p. 34-41, 2013. DOI: 10.1590/S198340632013000100009

RADEMACHER, W. Growth retardants: effects on gibberellin biosynthesis and other metabolic pathways. Annual Review of Plant Physiology and Plant Molecular Biology, Palo Alto, v. 51, n. 1, p. 501-531, 2000. DOI: 10.1146/annurev.arplant.51.1.501

RAJALA, A.; PELTONEN-SAINIO, P. Plant growth regulator effects on spring cereal root and shoot growth. Agronomy Journal, Madison, v. 5, n. 93, p. 936-943, 2001. DOI: 10.2134/agronj2001.934936x

RODRIGUES, O.; DIDONET, A. D.; TEIXEIRA, M. C. C.; ROMAN, E. S. Redutores de crescimento. Passo Fundo: Embrapa Trigo, 2003. 18 p. (Embrapa Trigo. Comunicado Técnico, 14).

SANGOI, L.; BERNS, A. C.; ALMEIDA, M. L.; ZANIN, C. G.; SCHWEITZER, C. Características agronômicas de cultivares de trigo em resposta à época da adubação nitrogenada de cobertura. Ciência Rural, Santa Maria, v. 37 , n. 6 , p. $1564-1570$, 2007. DOI: $10.1590 / \mathrm{S} 0103-$ 84782007000600010

SCHWERZ, F.; CARON, B. O.; SCHMIDT, D.; OLIVEIRA, D. M.; ELLI, E. F.; ELOY, E. ROCKENBACH, A, P. Growth retardant and nitrogen levels in wheat agronomic characteristics. Cientifica, Jaboticabal, v. 43, n. 2, p. 93-100, 2015. DOI: 10.15361/1984-5529.2015v43n2p93-100

SILVA, J. A. G.; FONTANIVA, C.; COSTA, J. S. P.; KRÜGER, C. A. M. B.; UBESSI, C.; PINTO, F. B.; ARENHARDT, E. G.; GEWEHR, E. Uma proposta na densidade de semeadura de um biotipo atual de cultivares de aveia. Revista Brasileira de Agrociência, Pelotas, v. 18 , n. 4, p. 253-263, 2012. Disponível em: http://www2. ufpel.edu.br/faem/agrociencia/v18n4/Artigo\%2001.pdf. Acesso em: 26 jun. 2019.

TAIZ, L.; ZEIGER, E. Fisiologia vegetal. Porto Alegre: Artmed, 2004. 719 p.

TEIXEIRA FILHO, M. C. M.; BUZETTI, S.; ALVAREZ, R. C. F.; FREITAS, J. G.; ARF, O.; SÁ, M. E. Resposta de cultivares de trigo irrigados por aspersão ao nitrogênio em cobertura na região do Cerrado. Acta Scientiarum Agronomy, Maringá, v. 29, n. 3, p. 421-425, 2007. DOI: 10.4025/actasciagron.v29i3.471

TEIXEIRA FILHO, M. C. M.; BUZETTI, S.; ARF, O.; ALVAREZ, R. C. F.; MAEDA, A. S.; SÁ, M. E. Resposta de cultivares de trigo ao nitrogênio com e sem tratamento fúngico. Revista Brasileira de Ciências Agrárias, Recife, v. 7, n. 4, p. 626-634, 2012. Disponível em: http://www. agraria.pro.br/ojs-2.4.6/index. php?journal=agraria\&pag $\mathrm{e}=$ article \&op=view\&path $\% 5 \mathrm{~B} \% 5 \mathrm{D}=\mathrm{v} 7 \mathrm{i} 4 \mathrm{a} 2110$ \&path $\%$ 5B\%5D=3571. Acesso em: 26 jun. 2019.

THEAGO, E. Q.; BUZETTI, S.; TEIXEIRA FILHO, M. C. M.; ANDREOTTI, M.; MEGDA, M. M.; BENETT, C. G. S. Doses, fontes e épocas de aplicação de nitrogênio influenciando teores de clorofila e produtividade do trigo. Revista Brasileira de Ciência do Solo, Campinas, v. 38 , n. 6 , p. $1826-1835$, 2014. DOI: $10.1590 / \mathrm{S} 0100-$ 06832014000600017

ZAGONEL, J.; FERNANDES, E. C. Doses e épocas de aplicação do regulador de crescimento afetando cultivares de trigo em duas doses de nitrogênio. Planta Daninha, Viçosa, MG, v. 25, n. 2, p. 331-339, 2007. DOI: $10.1590 / \mathrm{S} 0100-83582007000200013$

ZAGONEL, J.; VENANCIO, W. S.; KUNZ, R. P.; TANAMATI, H. Doses de nitrogênio e densidades de plantas com e sem um regulador de crescimento afetando o trigo, cultivar OR-1. Ciência Rural, Santa Maria, v. 32, n. 1, p. 25-29, 2002. DOI: 10.1590/S010384782002000100005 
